\title{
Yield response of rice in Nigeria: A co-integration analysis
}

\author{
David Boansi
}

Department of Economic and Technological Change, Center for Development Research (ZEF), University of Bonn, Germany

Email address:

boansidavid@rocketmail.com (D. Boansi)

\section{To cite this article:}

David Boansi. Yield Response of Rice in Nigeria: A Co-Integration Analysis. American Journal of Agriculture and Forestry. Vol. 2, No. 2, 2014, pp. 15-24. doi: 10.11648/j.ajaf.20140202.11

\begin{abstract}
To help bridge information gap in supply response studies for Nigeria and inform policy decision on how the demand-supply gap for rice in Nigeria could be bridged, the current study through the use of Johansen's Full Information Maximum Likelihood test estimated a yield response model for Nigeria using national level data for the period 1966-2008. The results suggest that, increasing yield levels for paddy rice in Nigeria and ensuring stability requires interplay of biophysical, socio-economic and structural forces. By estimates for the current study, bridging of the demand-supply gap can be realized through initiation of measures to address inefficiencies in the supply chain to ensure appropriate transmission of price increment, promotion of local rice consumption to ensure ready market for farmers in times of increasing output, addressing soil fertility challenges through efficient use of fertilizer and regular management of fertility of rice fields, and increasing farmers access to credit to help them meet cost of relevant inputs of production. The latter suggestion could to a greater extent incite appropriate response of farmers to both price and non-price incentives in the country. Diagnostic tests conducted indicate that the residual series is normally distributed, non-serially correlated and homoscedastic.
\end{abstract}

Keywords: Co-Integration, Yield, Error Correction Model, Nigeria, Prices

\section{Introduction}

With a population estimate of $174,507,539$ persons and population growth rate of $2.54 \%$, Nigeria happens to be not only the leading producer of rice in West Africa, but also among the leading importers of the commodity. Although endowed with a strong agricultural and natural resources base, as well as favorable climatic conditions for agricultural production, an amount of about billion is spent daily by Nigeria on importation of rice [1]. Hindered by inconsistent policies on rice, improper methods of production used by farmers, high costs and scarcity of vital inputs of production, etc, local rice production for Nigeria has failed to catch up with the increasing pace of consumption. By estimates observed from the agricultural production database of FAO for Nigeria, the gap between domestic demand of rice for food (as against feed and other uses) has widened since the late 1990s.

Treated with benign neglect prior to independence due to self-sufficiency, rice has become a strategic and political commodity in Nigeria, attracting much attention due to its increasing role in the diet of the populace and its daily drainage of foreign exchange through imports. Rice used to be classified as a luxury food item prior to independence; it however now holds the status of a staple food, replacing cassava and yam among others [12]. The consumption of rice in spite of increasing prices induced through high tariff imposition has been increasing since the year 1976. Per capita consumption of rice in the country increased from as low as $3.4 \mathrm{~kg} / \mathrm{year}$ in 1976 to $20.9 \mathrm{~kg} / \mathrm{yr}$ in 2009 [15], an increase of over $500 \%$. Production has however failed to catch up with the increasing demand for rice, leading to widening of the gap between domestic production and demand, increasing the role of imported rice in diets of the Nigerian populace, and making the country a net importer of the commodity in the process.

Various trade policies purposed on improving local rice production and marketing systems of the country have been adopted and applied by previous regimes to help reverse the net importer status of the country. Among such measures are imposition of tariffs, quantitative restrictions on imports through the use of quota, and outright ban on imported rice [12]. In spite of past and present efforts, the demand-supply gap persists. Like other West African countries, bridging of the rice demand-supply gap in Nigeria, besides the aforementioned trade policy measures, have been sought through expansion of area for production as against intensification (purposed on improving productivity). With area harvested of rice having generally depicted an increasing trend between the years 1976 and 
2009, output of rough rice has more or less stagnated between the years 1989 and 2007. As shown in Figure1, the latter observation was accompanied by a general declining trend in yields between the two aforementioned years (1989 and 2007). Yield decreased from 2tonnes/ha in 1989 to 1.3tonnes/ha in 2007 .

It is believed that coupling extensification (area expansion) measures with productivity-enhancing measures could produce better outcome in terms of output of rough rice, than sole expansion of harvested area. To achieve this however, there arises a need to identify and estimate the magnitude and effects of key determinants of rough rice yields and to inform policy decision on how beneficial implications of growth-enhancing determinants could be maximized and adverse implications from inhibitors minimized. Meeting this need is the goal of the present study. Magnitude and effects of such key determinants is sourced through the use of Johansen's Full Information Maximum Likelihood test.

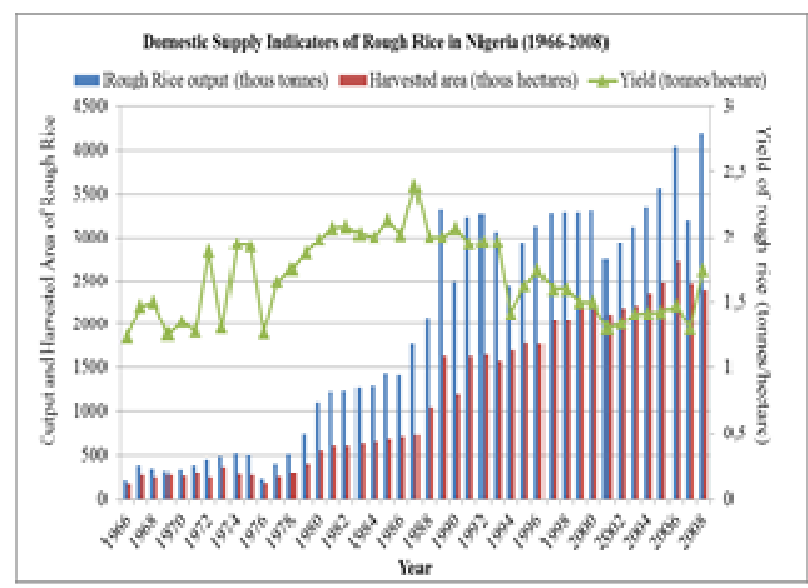

Data Source: IRRI (World Rice Statistics, FAO data)

Figure 1. Domestic supply indicators of rice in Nigeria
In a study by Norman and Kebe (2006) on "African smallholder farmers: rice production and sustainable livelihoods", it was revealed that rice production in most African countries lags well behind demand due to low productivity of farmers' fields. Most developing countries go after area expansion in pursuit of bridging their respective demand-supply gap for rice, placing quite minimal emphasis on productivity. Some important questions that need answering are "How long can we keep on expanding area under rice cultivation? How far can we get with this?" In his speech at the launch of a seminar organized by CGIAR Fund Office, Dr Robert Zeigler (Director General of the International Rice Research Institute (IRRI) placed an advise that

"Because of rapid population growth and diminished harvest due to climate change and other weather related stress, such as severe drought and floods, global demand for rice will outstrip supplies unless concerted action is taken now to boost yield growth and improve the management of water, land and other resources on which production depends" [36]

In spite of efforts in line with area expansion put forth so far by many developing countries, the demand-supply gap persists in majority of such countries, notably countries in West Africa. The problem therefore as identified by Norman and Kebe [29], and affirmed by Zeigler [36] is with yield as a component of output as against harvested area. With anticipated increases in population growth and corresponding increases in infrastructure development, there will come a time when expansion will no more be an option. Must we wait until that time is due? What then will we be protecting for posterity? This line of reasoning has over a decade now given most researchers a purpose to sacrifice much time, money and energy into finding alternative measures to help increase yields of major cereals and non-cereals on which farmers and most rural and sub-urban inhabitants depend for sustenance.

\subsection{Local, Regional and Continental Rice Yields}

Table 1. Local, regional and continental rice yields

\begin{tabular}{|c|c|c|c|c|c|}
\hline \multirow{2}{*}{ Region / Country } & \multicolumn{5}{|c|}{ YEAR (PERIOD) } \\
\hline & 1961- 1970 & 1971- 1980 & 1981- 1990 & 1991- 2000 & 2001- 2010 \\
\hline Côte d'Ivoire & 1.00 & 1.21 & 1.17 & 1.34 & 1.88 \\
\hline Egypt & 5.19 & 5.37 & 5.98 & 8.22 & 9.68 \\
\hline Ghana & 1.11 & 0.92 & 1.11 & 1.87 & 2.19 \\
\hline Indonesia & 1.91 & 2.75 & 3.96 & 4.35 & 4.68 \\
\hline Nigeria & 1.26 & 1.69 & 2.08 & 1.69 & 1.52 \\
\hline Pakistan & 1.65 & 2.35 & 2.45 & 2.73 & 3.15 \\
\hline Thailand & 1.81 & 1.85 & 2.03 & 2.37 & 2.91 \\
\hline Vietnam & 1.93 & 2.10 & 2.77 & 3.71 & 4.90 \\
\hline Western Africa & 1.15 & 1.34 & 1.58 & 1.64 & 1.71 \\
\hline Northern Africa & 5.15 & 5.27 & 5.93 & 8.14 & 9.58 \\
\hline Africa & 1.82 & 1.84 & 1.93 & 2.17 & 2.37 \\
\hline Americas & 2.08 & 2.25 & 2.76 & 3.70 & 4.82 \\
\hline Asia & 2.11 & 2.55 & 3.30 & 3.80 & 4.19 \\
\hline World & 2.11 & 2.52 & 3.23 & 3.73 & 4.12 \\
\hline
\end{tabular}

Source: Author's computation (with FAO data from IRRI) 
As seen from Table 1, the issue of low yield is seen as a problem not only with countries in West Africa, but some high esteemed countries in world rice trade as well. Analyzing systematically by regions and continents, rice yields for the West African sub-region are well below figures for the African continent for all the five decadal periods considered. Excluding the period 2001-2010 for Côte d'Ivoire, and 1991-2000 and 2001-2010 for Ghana, rough rice yields for the two countries are well below that for the sub-region and African continent for all the five decadal periods. Although generally above figures for the sub-region, rough rice yields in Nigeria (with the exception of average yield for the period 1981-1990, 2.08tonnes/ha) are lower than figures for the continent. Similarly, average yields of rough rice for the African continent are well below world averages for all the five decadal periods.

Yields however in Egypt are not just above figures for the North African sub-region, but almost twice world averages. Similarly, figures observed for Northern Africa are well above world averages, West African averages, averages for the African continent, and even those observed for Asia and the Americas. Although average yields observed for Asia are above world averages and those for Africa, noted countries in world rice production and trade like Pakistan and Thailand have average yield figures well below figures for the Asian continent, and world averages for all the five decadal periods. Excluding the period 1961-1970, average yields for Indonesia are well above average figures for the Asian continent and above world averages. In contrast however, average yield figures for Vietnam are well below figures for the Asian continent except for the period 2001-2010. Average yield figures for Vietnam are above world averages only in the periods 1991-2000 and 2001-2010. Similarly, average yield figures for the Americas, although above averages for Africa, Asia in the period 2001-2010, and world averages for the periods 1991-2000 and 2001-2010, they are generally below average yields in Asia, Northern Africa and world averages for majority of the period.

\section{Literature Review}

Agricultural supply response (be it output, acreage or yield) has been a fundamental issue and continues to attract much attention due to uncertainty in future food supply and crisis in the past (most notably, the commodity crisis of the year 2008 which impacted adversely on most households in the Sudan-Sahel region of West Africa). These concerns are held mostly due to the volatile nature of prices for agricultural commodities on the world market and to climatic influences on crop production.

Supply response studies observed so far in literature have been on either estimating response across a group of crops or for a specific crop of interest to the country under study. In either case, supply decision of farmers is assumed to be in line with economic theory; thus being influenced by price and non-price factors. Among the common non-price factors suggested in literature are access to capital, extension services, agro-climatic conditions, agricultural labor availability, area of land cultivated, status of rice farmers, and use of fertilizer [27, 7, 8, and 35]. Real producer price of rice, real producer price of competitive field crops like maize, world price of rice and maize with important indirect effects to producers, and price of relevant agro-chemicals like fertilizer $[24,26]$ are among the price-related drivers of supply identified so far in literature.

Defined as the variation of agricultural output as a result of variation in price and key inputs, supply response according to Molua [25] is explained by biophysical, socioeconomic and policy factors. For over three decades now, various theories have been developed and applied by economists to explain the dynamics of supply in agriculture and its key sub-sectors. Ideally, in line with economic theory, supply functions have been estimated on the assumption that the primary drivers of market supply of any given commodity are inputs, output and the state of technology [8]. Ahmed and Siddiqui [3] estimated supply response as a function of output and input prices, together with quasi-fixed inputs and supply shifters like technical change and policy intervention.

In a study on supply responsiveness of Indian farmers, Cummings [11] suggested that supply response for a given crop is equivalent to the response of acreage under cultivation to changes in economic and non-economic factors, and that estimates obtained from acreage response studies could be considered fairer reflections of supply response for a given commodity. Molua [24] however advised that positive signals observed from acreage response models will translate appropriately into output only on the employment of other vital complementary factors of production such as pesticides, fertilizer, high yielding varieties, other farm chemicals, improved cropping techniques and better farm management methods. Increasing production of a given crop can be achieved through expansion of the area under cultivation, increasing cropping intensity or increasing produce per unit area (yield) [13].

Beside these, other constraints have been noted to impact significantly on output of major staple crops, most importantly wheat, maize, rice, sorghum and millet for West Africa and other rice producing and importing regions. Among such constraints are exchange rate policies and pricing policies; fiscal policy, fertilizer policy, land policy, etc. [30].

\section{Research Methodology}

\subsection{Analytical Framework}

Co-integration analysis has so far been performed in supply response studies using the Engle-Granger two-step estimation technique [14], the residual-based approach of Phillips and Ouliaris [32], or the Johansen Full Information 
Maximum Likelihood test [21]. For the purpose of the current study however, the Johansen Full Information Maximum Likelihood test is used. This estimation technique is chosen because, unlike the other two methods which assume a single co-integrating vector, the Johansen method allows for all possible co-integrating relationships and permits empirical determination of the number of co-integrating vectors [22]. In addition, short-run coefficients are estimated in such a way that they are guided by and consistent with long-run relationships.

The Johansen approach commences with the definition of a Vector Autogression given by

$$
\mathrm{X}_{\mathrm{t}}=\prod_{1} \mathrm{X}_{\mathrm{t}-1}+\prod_{2} \mathrm{X}_{\mathrm{t}-2}+\ldots+\prod_{\mathrm{p}} \mathrm{X}_{\mathrm{t}-\mathrm{p}}+\mu_{\mathrm{t}}
$$

Where $\mathrm{X}_{\mathrm{t}}$ is an $(n \times 1)$ vector of $I(1)$ variables, $\prod_{1}$ through $\prod_{\mathrm{p}}$ represent $(m \times m)$ matrix of coefficients, and $\mu_{\mathrm{t}}$ is $(n \times 1)$ vector of white noise errors. With the assumption that $X_{t}$ is non-stationary, equation (1) can be re-parameterized or written in an error correction form as;

$$
\Delta \mathrm{X}_{\mathrm{t}}=\Gamma_{1} \Delta \mathrm{X}_{\mathrm{t}-1}+\Gamma_{2} \Delta \mathrm{X}_{\mathrm{t}-2}+\ldots+\Gamma_{\mathrm{p}-1} \Delta \mathrm{X}_{\mathrm{t}-\mathrm{p}+1}-\prod \mathrm{X}_{\mathrm{t}-\mathrm{p}}+\mu_{\mathrm{t}}
$$

Where $\quad \Gamma_{1}=\prod_{1}-\mathrm{I}, \quad \Gamma_{2}=\prod_{2}-\Gamma_{1}, \quad \Gamma_{3}=\prod_{3}-\Gamma_{2} \quad$ and $\Pi=\mathrm{I}-\prod_{1}-\prod_{2}-. .-\prod_{\mathrm{p}}$

$\Gamma i$ gives the short-run estimates while $\prod$ gives the long-run estimates. The matrix $\prod$ determines the extent to which a given system is co-integrated and is called the impact matrix. This implies that, information on the number of co-integrating relationships among the variables in $X_{t}$ is given by the rank of the matrix $\prod$. If the rank of $\prod$ matrix $r$, is $0<\mathrm{r}>\mathrm{n}$, there are $\mathrm{r}$ linear combinations of the variables in $X_{t}$ that are stationary [22]. Thus $\prod$ can be decomposed into two matrices $\alpha$ and $\beta$, where $\alpha$ represents the error correction term and measures the speed of adjustment in $\Delta X_{t}$ and $\beta$ contain $r$ co-integrating vectors. Should there be variables which are $I(0)$ and are significant in the long-run co-integrating space but affect the short-run model, equation (2) is re-written as follows:

$$
\Delta \mathrm{X}_{\mathrm{t}}=\Gamma_{1} \Delta \mathrm{X}_{\mathrm{t}-1}+\Gamma_{2} \Delta \mathrm{X}_{\mathrm{t}-2}+\ldots+\Gamma_{\mathrm{p}-1} \Delta \mathrm{X}_{\mathrm{t}-\mathrm{p}+1}-\prod \mathrm{X}_{\mathrm{t}-\mathrm{p}}+\mathrm{vD}_{\mathrm{t}}+\mu_{\mathrm{t}}
$$

Where Dt represents the $I(0)$ variables

In identifying the number of co-integrating vectors, two likelihood ratio (LR) tests are used. These are the trace test and the maximum eigenvalue tests. The trace test is a joint test of the null hypothesis of $\mathrm{r}$ co-integrating vectors against the alternative that it is greater than $r$. The trace test statistic is given as

$$
\operatorname{Jtrace}(\mathrm{r})=-\mathrm{T} \Sigma^{\mathrm{p}}{ }_{\mathrm{i}=\mathrm{r}+1} \ln \left(1-\lambda_{\mathrm{i}}\right)
$$

The maximum eigenvalue test on the other hand conducts separate tests on the individual eigenvalues for a null hypothesis that the number of co-integrating vectors is $r$, against an alternative of $\mathrm{r}+1$. The test statistic for the maximum eigenvalue test is given as

$$
\operatorname{Jmax}(\mathrm{r}, \mathrm{r}+1)=-\mathrm{T} \ln \left(1-\lambda_{\mathrm{r}+1}\right)
$$

The trace test according to Harris [18] shows more robustness to both skewness and excess kurtosis in the innovations than the maximum eigenvalue test. It is therefore selected over the maximum eigenvalue test in the present study. Kuwornu et al [22] suggested that in using the Johansen Full Information Maximum Likelihood test, the endogenous variables included in the Vector Autoregression (VAR) are all $I(1)$, also the additional exogenous variables which explain the short-run effect are $I(0)$.

In spite of the advantages held by the chosen method to co-integration analysis, the Johansen Full Information Maximum Likelihood test has a weakness of being heavily reliant on asymptotic properties and is sensitive to specification errors in limited samples. To ensure correct specification of the VAR or VECM (Vector Error Correction Model) and adherence to the appropriate standard Gaussian properties, there is a need to set appropriate lag length(s) and include variables that are likely to affect the short-run behavior of the model. Omitting important conditional variables could lead to residual misspecification [19]. In selecting the lag length, emphasis so far in literature has been placed on the Akaike information criterion (AIC), the Schwarz information criterion (SC) and the Hanna-Quinn information criterion (HQ).

\subsection{Yield Response Model}

This study estimated the yield response of paddy rice in Nigeria using the following implicit response function

$$
\text { LgYld= f (LgRR, LgOP, LgRM, LgFU, LgNRA) }
$$

Yield ( $\mathrm{LgYld}$ ) is considered a function of real producer price of rice (LgRR), aggregate output of paddy rice ( $\mathrm{LgOP}$ ), real producer price of maize $(\mathrm{LgRM})$, total quantity of fertilizer used (LgFU), and nominal rate of assistance (NRA). All the variables except nominal rate of assistance (NRA) are expressed in the $\log$ form ( $\mathrm{LgX}$ means $\mathrm{X}$ in $\log$ form). Data on yield, aggregate output and total quantity of fertilizer used were sourced from the World Rice Statistics of IRRI (FAO data for yield and output). Nominal producer price of rice and maize gathered from the agricultural production database of FAO were deflated into real price using 2005-based consumer price index (CPI) series for Nigeria from the World Rice Statistics of IRRI [20]. Data on nominal rate of assistance was gathered from the updated excel file of the World Bank on National and Global Agricultural Trade and Welfare Reduction Indexes, 1955 to 2010 [6].

\section{Results and Discussion}

\subsection{Unit Root Test}

As a vital step in co-integration analysis, the data gathered was tested for stationarity of the respective series and to ascertain the order of integration of the individual series. This, in co-integration analysis is considered a vital step in the data generation process and in the choice of estimator. For co-integration analysis to be deemed valid, Towsend [33] 
suggested that all the series considered must be integrated of the same order, usually I(1). Although several unit root tests have been suggested and applied in literature (most notably the Dickey-Fuller and Augmented Dickey-Fuller tests), the Phillips-Perron (PP) unit root test was used in the present study for verification of data. The PP test used can be viewed as a Dickey-Fuller statistic that has been made robust to serial correlation by using the Newey-West [28] heteroskedasticity-and-autocorrelation-consistent matrix estimator. Trend and intercept terms were included in specification for level, with only an intercept term being used in specification for first difference. The results are presented in Table 2 .

The results of the unit root tests show that all the series are non-stationary at level except for nominal rate of assistance (NRA) which was found stationary at the $1 \%$ significance level. All the non-stationary series however became stationary on first difference at the $1 \%$ significance level. The results therefore underscore non-stationarity in the data set at level.

Table 2. Results of unit root test

\begin{tabular}{ccccc}
\hline Series & level & BW & First. diff & BW \\
\hline LgYld & -3.367 & 4 & $-10.838 * * *$ & 0 \\
LgRR & -2.056 & 0 & $-5.335 * * *$ & 5 \\
LgOP & -2.455 & 0 & $-8.248 * * *$ & 4 \\
LgRM & -3.299 & 2 & $-14.764 * * *$ & 40 \\
LgFU & -1.364 & 3 & $-6.803 * * *$ & 3 \\
NRA & $-4.519 * * *$ & 2 & $-15.242 * * *$ & 16 \\
Crit. Val. & -3.521 & & -2.935 & \\
\hline
\end{tabular}

NB: $95 \%$ confidence level for critical values, $* * * 1 \%, * * 5 \%$

\subsection{Results of Co-Integration}

Having established the order of integration of the respective data series, an appropriate Vector Autoregression (VAR) for the study was defined, the optimum number of lags determined and the number of co-integrating equation(s) identified through the trace test. In defining the VAR, the variable NRA (nominal rate of assistance) was considered exogenous. In determining the optimum number of lags, a maximum of 3 lags was initially set due to the number of observations (1966-2008). From the output obtained, the Akaike information criterion (AIC) selected lag order three, whiles the Schwarz information criterion (SC) and Hannan-Quinn information criterion (HQ) selected lag order one. This study thus selected lag order one for the VAR model.

A test for number of co-integrating vector(s) based on trace statistic (assuming no deterministic trend) also indicated "one" co-integrating equation at the 0.05 level. By this, it can be concluded that the variables in the model are co-integrated. With co-integration having been confirmed, a dynamic error correction model or vector equilibrium correction model [23] instead of a VAR becomes more appropriate. Opting for a VECM instead of VAR, the statistical package EViews estimated the long-run elasticities with respect to real producer price of rice, aggregate output of paddy rice, real producer price of maize, and total quantity of fertilizer used. The normalized equation (variables in log) observed for yield of rough rice for Nigeria is given as

Yld $=0.479 \mathrm{RR}+0.194 \mathrm{OP}-1.042 \mathrm{RM}+0.005 \mathrm{FU}+4.861$

$$
\begin{array}{lllll}
(0.087) & (0.073) & (0.157) & (0.043) & (0.993)
\end{array}
$$

$$
(5.483)^{* * *}(2.644)^{* * *}(-6.642)^{* * *}(0.114) \quad(4.895)^{* * *}
$$

The dynamic error correction model for eq(7) in this study is presented as

$$
\begin{gathered}
\Delta \mathrm{Yld}_{\mathrm{t}}=\Gamma_{0}+\Sigma_{\mathrm{i}=0}^{\mathrm{n}} \Gamma_{1 \mathrm{i}} \Delta \mathrm{Yld}_{\mathrm{t}-1}+\Sigma_{\mathrm{i}=0}^{\mathrm{n}} \Gamma_{2 \mathrm{i}} \Delta \mathrm{RR}_{\mathrm{t}}+\Sigma_{\mathrm{i}=0}^{\mathrm{n}} \Gamma_{3 \mathrm{i}} \Delta \mathrm{OP}_{\mathrm{t}}+ \\
\Sigma_{\mathrm{i}=0}^{\mathrm{n}} \Gamma_{4 \mathrm{i}} \Delta \mathrm{RM}_{\mathrm{t}}+\Sigma_{\mathrm{i}=0}^{\mathrm{n}} \Gamma_{5 \mathrm{i}} \Delta \mathrm{FU}_{\mathrm{t}}+\Gamma_{6 \mathrm{i}} \mathrm{NRA}_{\mathrm{t}}-\alpha \mathrm{EC}_{\mathrm{t}-1}
\end{gathered}
$$

Where EC is the error correction term and " $\alpha$ " represents the rate at which deviations from the long-run equilibrium are restored (speed of adjustment). The negative sign on the error correction term ensures that any adjustment made or observed in the short-run is guided by and consistent with the long-run equilibrium relationship. A significant " $\alpha$ " validates the existence of long-run relationship between the variables. Having defined and estimated the error correction model, the estimates where tested for appropriate standard Gaussian assumptions. The residual series was found to be normality distributed, non-serially correlated and homoscedastic. Higher order test for serial correlation up to 20 lags still showed no sign of autocorrelation.

The results indicate that in the long-run, yield of paddy rice is dependent on real producer price of rice, aggregate output of paddy observed and real producer price of maize. In the short-run however, observed yield is dependent on lagged yield, real producer price of rice, aggregate output of paddy rice, real producer price of maize, and the quantity of fertilizer used. A total of about $59.82 \%$ of variation in yields of paddy rice for Nigeria is explained by variables in the implicit yield response function specified in the current study. Approximately $26 \%$ of total deviations in yield from the long-run equilibrium are restored in the current period, and this restoration is found significant at the 5\% level.

Yields in Nigeria are reportedly low due to low application of vital agro-chemicals like fertilizer and pesticides, low mechanization of rice farms, over-reliance on rainfall, limited use and inappropriate management of irrigation facilities, limited availability of labour needed for carrying out vital cultural practices like weeding, pest control among others, broad use of genetically inferior varieties that exhibit low productivity, low producer price in the output market which limits incentive to invest appropriately in yield enhancing innovations and limited delivery of extension services [12,34, and 31]. Pull in yields resulting from the inter-play of these biophysical, socio-economic and structural constraints have for over two 
decades now led not only to irregular supply of local rice, but also to yields well below climatic potential. Improvement observed in current yield, by estimate for the short-run model, is followed by significant declines in yields in the short-term, reflecting incidence of significant nutrient withdrawal in times of yield increment and subsequent ineffective replenishment.

Table 3. ECM results for yield of paddy rice

\begin{tabular}{cccc}
\hline & Coeff & Std. Error & t-statistic \\
\hline$\Delta \ln$ Yld (-1) & -0.3768 & 0.1184 & $-3.1823^{* * *}$ \\
$\Delta \ln$ RR & 0.2099 & 0.0845 & $2.4835^{* *}$ \\
$\Delta \ln$ OP & 0.3103 & 0.0739 & $4.2005^{* * *}$ \\
$\Delta \ln$ RM & -0.1993 & 0.0932 & $2.1389^{* *}$ \\
$\Delta \ln$ FU & 0.1558 & 0.0508 & $3.0644^{* * *}$ \\
NRA & -0.0515 & 0.0368 & -1.4015 \\
EC & -0.2599 & 0.1232 & $-2.1092^{* *}$ \\
$\mathrm{R}^{2}$ & 0.6584 & J-Bera & $0.994(0.609)$ \\
Adj-R ${ }^{2}$ & 0.5982 & Q-stat (1) & $1.664(0.197)$, \\
S.E of reg. & 0.1044 & B-G LM & $2.066(0.160)$, \\
L-likelihood & 38.3099 & ARCH T. & $0.014(0.906)$ \\
AIC & -1.5273 & Mean DV & 0.0043 \\
SC & -1.2348 & S.D.DV & 0.1647 \\
HQ & -1.4208 & SS resid & 0.3704 \\
D-W Stat. & 2.3210 & & \\
\hline
\end{tabular}

NB: $* * * 1 \%, * * 5 \%$,

A $1 \%$ increase in yield observed in time t-1 may although be statistically significant by current estimates, along current levels, such improvement may not be sufficient enough to ensure significant increase in farmers' income, a condition vital for meeting future field improvement and soil fertility management needs. In the present study, a $1 \%$ increase in lagged yield is observed to trigger a $0.377 \%$ decrease in yields for the subsequent years. This decrease is found significant at the $1 \%$ level. Monitoring trends in harvested area and yields in the country, this observation could, beside the aforementioned constraints be attributed to major increases in area harvested following periods of yield increment, thereby creating much competition for limited nutrients available to the rice plants due to significant withdrawal. With their production decisions being influenced by current land tenure system of the country, most of the farmers invest a greater share of increases observed in their incomes as a result of major yield improvements on acquiring more lands, rather than investing in land improvement (knowing that the land is leased out to them only for a short-period of time). This consequently has significant adverse implication for future rice yields.

Having been identified as one of the constraints precluding the achievement of improved and stable yields, low producer price of rice in the output market has together with limited access to credit precluded most farmers from responding appropriately to non-price policy incentives purposed on increasing output. Among the vital inputs for rice production in the tropics are labour, water supply (irrigation) and application of agro-chemicals. These inputs account for a greater share of cost of production of local rice in West Africa (labor being prioritized for Nigeria due to more remunerative off-farm employment). In the presence of limited access to credit, the alternative means by which farmers could increase their financial base is primarily through increases in price of their produce and increases in the produce. Hindered by poor marketing structure however (as seen also in Ghana, see [5, 9]), increases in the initial low price of rice are usually poorly transmitted in the short-run and some farmers in areas with poor roads are to some extent precluded from sharing in such increments due to poor bargaining power and limited storage infrastructure (which course them to sell their produce at give-away prices to minimize post-harvest losses). In the long-run however, following accumulation of profits and improvements in the market structure to facilitate a relatively better transmission of price increment, farmers are able to meet vital cost of production better than in the short-run. This leads to anticipated high effect of own price increments in the long-run on yield than in the short-run.

Yield of rice is in the present study observed to increase by $0.210 \%$ and $0.479 \%$ respectively in the short-run and long-run for a $1 \%$ increase in real producer price of rice. Each of these effects is found significant at the $1 \%$ level. Using an autoregressive distributed lag model approach to estimate rice output supply response to changes in real prices for Nigeria, Ogazi [30] found insignificant short-run own-price coefficient of 0.043 and at $5 \%$ significance level a long-run coefficient of 0.271 . In as much as the coefficients observed for yield in the present study compare favorably with the coefficients observed for output in the study by Ogazi, it is noted that own price coefficients in either study are inelastic. This observation reflects structural constraints faced by farmers mostly in access to and structure of the market. In addition, Ogazi observed an error correction term of -0.575 for the output response model, significant at the $1 \%$ level. A coefficient of -0.260 (significant at the $5 \%$ level) observed in the present study indicates that adjustments to long run equilibrium in output for Nigeria are faster than in yields.

In as much as most studies hold unto the dependence of output on yield, the current study is founded on the belief that in a country where productivity of farmers' fields is identified to be low, changes in output to a greater extent shape yields in both the long- and short-run. Effect of changes in output on yield could be either positive or negative depending on how well derived benefits from such increments are re-invested in the fields to improve and sustain future yields. Increment in output is under normal circumstances accompanied by nutrient withdrawal regardless of whether or not output is driven more by increases in area expansion than in yield. Should benefits from such increments be appropriately re-invested in the fields with a purpose of replenishing lost nutrient, a significant positive association could be observed between 
increments in output and yield in subsequent years. Failure however to ensure appropriate investment in the fields following output increments could lead to adverse implications.

In the present study, aggregate output of paddy rice had coefficients of 0.310 and 0.194 respectively for the short- and long-run. The coefficient observed for the short-run is significant at the $1 \%$ level, while that for the long-run is found significant at the $5 \%$ level. This implies that a $1 \%$ increase in output of rice leads to a $0.310 \%$ increase in yield in the short-run and $0.194 \%$ increase in the long-run. Although long-run coefficients are usually larger than the short-run coefficients, the respective coefficients observed in this study are economically and practically intuitive. In the short-run where most factors of production are considered fixed, increases in output could increase the capital and financial base of farmers to enable them invest appropriately in their fields and to meet other vital production costs, most importantly the cost of fertilizing and managing the fertility of rice fields. Majority of investments made in such situation are mostly purposed on increasing productivity (and in some cases expanding area of production in communities where land tenure pulls are minimum).

In the long-run however where almost all factors of production are considered variable, the relative share of increase in capital and financial base of farmers (due to increases in output) invested with productivity enhancement motive reduces due to increases in cost of other inputs of production and vital cultural practices. There usually is an increase in area harvested of rice in the long-run, and with this comes intensified competition by rice plants for limited nutrients in the soil due to low dosages of current fertilizer application and poor fertility status of current rice fields (amidst issues with pest and disease control, as well as water management). In as much as significant increases in financial base of farmers through increases in output (which also has some nutrient withdrawing implications) may help increase productivity through investment in productivity enhancing innovations, adverse effects from other forces in the long-run may be larger than in the short-run, thereby pulling (negating) more of the contribution from any investment made in the long-run than in the short-run.

By production theory, farmers are considered to be profit maximizers and cost minimizers. Their decisions are under normal circumstances made in such a way that, profits are maximized through better allocation of their resources, minimizing cost as well in the process. Facing price transmission challenges in the rice market (on the assumption that transmission is better in the maize market) amidst difficulty in accessing credits, as risk averse individuals and rationale beings, farms usually allocate resources in favor of ventures that yield higher returns at the expense of the low yielding ventures. Focusing on rice and maize as two competing field crops, ceteris paribus, farmers are expected to allocate more resources into rice production should conditions in the rice sub-sector (most importantly prices) be favorable than in the maize sub-sector. The opposite is expected should conditions be more favorable in the maize sub-sector.

By the coefficients observed in this study for real producer price of maize, it is inferred that a $1 \%$ increase in real producer price of maize leads to a $0.199 \%$ decrease in yield in the short-run and $1.042 \%$ decrease in the long-run. The short-run effect is found significant at the 5\% level, while the long-run effect is significant at the $1 \%$ level. This observation is solely attributed to resource allocation in favor of maize production (thus withdrawal of resources from rice production into maize production). The nature of this re-allocation of resources however differs between the short-run and the long-run. In the short-run where most factors of production are considered fixed (most importantly land), the issue of withdrawal of resources from rice production into maize production is basically limited to labor and vital agro-chemicals. In the long-run, the degree of flexibility in production decisions is quite higher due to the ability to vary almost all vital inputs of production including land. By this, the withdrawal of resources from rice production goes beyond the labour and agro-chemical look for the short-run. In the long-run, land could even be diverted for maize production should economic and bio-physical conditions of production be more favorable. This explains the relatively low and inelastic coefficient observed in the short-run and the elastic coefficient observed in the long-run. This observation indicates that rice farmers in Nigeria respond more to price incentives for competitive field crops like maize than own-price incentives. This could be due to differences in efficiency of the supply chain for both commodities.

Characterized by large agro-ecological heterogeneity $[2,4]$, rice fields in Nigeria respond differently to fertilizer application base on other bio-physical and water supply constraints. Heterogeneous environments tend to exhibit substantial spatial and temporal variability in soil properties $[10,17]$. In as much as some fields respond positively to fertilizer application in both the long and short-run, some fields respond positively only in the short-run (following the law of diminishing returns), while others give totally mixed signals. By economic theory however, assuming a fixed area of production in the short-run (as farmers are believed to be constrained in regard to what production decision they can make), the "Flower-pot law" postulates that both marginal and average productivities initially increase, but eventually they both decrease. Information on these indicators is mostly useful in homogenous fields and in estimating responses at the farm/firm and to some extent regional level. At the national level, information on fertilizer use fails to provide details on regional and farm level differences in actual use but generally gives the aggregate figure for the country.

The aggregate provides no distinction between the amounts used during the main cropping season and that for the lean season in areas with two seasons of production (mostly in regions where the irrigated system of production dominates). Use of aggregate fertilizer for this yield response study is therefore purposed on identifying how 
changes in aggregate fertilizer used generally shape national yields of rice in the country, placing no major emphasis on the optimum needed due to agro-ecological heterogeneity and to likely differences in the true optimum for the respective agro-ecologies.

In this study, coefficients of 0.156 and 0.005 were respectively observed in the short-run and long-run for the variable "FU" (total quantity of fertilizer used). The short-run effect is found significant at the $1 \%$ level. The long effect however is not significant. This implies that, a $1 \%$ increase in total quantity of fertilizer used in the short-run leads to a $0.156 \%$ increase in average yield of paddy rice, but increases observed in the long-run are not significant. This observation could have been considered consistent with the "Flower pot law" should area of land under cultivation be deemed constant in both the long and short-run, other vital variables held constant in the long-run and the area of production be considered homogenous. With this however not being the case, the coefficients observed in this study reflect general inefficiency in use of fertilizer in Nigeria as quantity of fertilizer used leads to inelastic changes in yields in both the long and short-run regardless of the significant response in the short-run (where most inputs of production are deemed constant).

The insignificant effect of quantity of fertilizer used on national yields in the long-run is attributed to differences in the rate of increase in fertilizer application and area harvested of rice, increasing cost of production in the long-run which offsets benefits from increases in fertilizer application, increasing cost of water and soil fertility management, and to weather and other biological factors whose effect lies beyond the scope of this study. This suggests that improving yields in the country in the long-run as against the short-run requires relatively complex interaction of forces.

The effect of nominal rate of assistance (NRA) on yield was found to be insignificant. In as much as assistance from government, mostly reflected by decreases in taxation of farm incomes and increases in tariffs on imports is expected to incite positive response from farmers, it equally leads to secondary distortion in input prices thereby offsetting any beneficial implications of the variable. Its' being positive or negative (and significant or not) usually depends on the extent to which one effect supersedes the other and to how consistent the measure is. A noted problem with this variable for Nigeria is inconsistency. NRA which to some extent reflects the degree of trade restriction in a country has depicted multiple-peaked oscillations in short term intervals for Nigeria. This observation discourages farmers from investing appropriately in their fields due to anticipated fear of competition in the rice market; hence the observed insignificant response of farmers to nominal rate of assistance.

\subsection{Limitations of Study}

In as much as this study tried to estimate yield response for Nigeria using secondary data at the national level and could not cover all relevant variables suggested in literature due to the large model estimation problem of the selected estimation technique [23] and to data accessibility challenges (for climate related variables like precipitation and temperature), the effect of such vital variables could not be captured in the study. Secondly, effect of the variable "FU" (quantity of fertilizer used) on yield estimated in the present study although reflect inefficiency in fertilizer usage in the country, the observed coefficients may not necessarily hold in some agro-ecologies due to large agro-ecological heterogeneity of rice fields in the country.

In addition, no optimum quantity of fertilizer application was estimated because an optimum for one production system in a given ecology may not hold for another due to likely spatial and temporal variability in soil properties and other bio-physical forces. Future research in estimating yield response could improve on this study by analyzing response at the farm or regional level to help determine optimum for the respective agro-ecologies. In so doing, the effect of variables like farmer's expertize, adoption and use of improved production technologies and vital climate variables like precipitation and temperature could be captured (for example in assessment of effect of climate variability on yields).

\section{Conclusion}

To help bridge information gap in supply response studies for Nigeria and inform policy decisions on how the demand-supply gap could be bridged in the near future, the current study through the use of Johansen's Full Information Maximum Likelihood test estimated a yield response model for Nigeria using secondary data for the period 1966 to 2008. The results show that in the long-run, yield is significantly dependent on real producer price of rice, aggregate output of paddy rice and on real producer price of maize (a competitive field crop). In the short-run however, yield is dependent on lagged yield, real producer price of rice, aggregate output of paddy rice, real producer price of maize, and quantity of fertilizer used. A total of about $59.82 \%$ of variations in yield of paddy rice for Nigeria is explained by variables in the model estimated. A total of about $26 \%$ of deviations from the long-run equilibrium for yield is restored in the current period, and this restoration was found significant at the $5 \%$ level.

Interestingly, rice farmers in the country were found to respond more to changes in price of maize than own-price for rice. This observation was attributed to likely differences in efficiency of the supply chain for rice and maize, with transmission of price increment presumed to be higher in the maize market than in the local rice market. Inelastic response of yield to changes in real producer price of rice, as was also observed by Ogazi [30], shows that farmers in Nigeria are precluded from responding appropriately to own-price incentives due to structural constraints they face. In as much as improvement in yields is presumed to stimulate growth in output, increases in output in countries 
with low fertility of farmers' fields like Nigeria is found in the present study to shape (increase) yields through increases in capital and financial base of farmers. The effect was however found to be higher in the short-run than in the longer run, due to anticipated pulls from other production factors in the long-run.

Although rice farmers are observed to use fertilizer inefficiently in their cropping activities, observed effects in the present study may not hold in some agro-ecological zones due to presumed heterogeneity in rice fields, and to likely spatial and temporal variability in soil properties. The effect of nominal rate of assistance on yield was found to be insignificant. This was attributed to inconsistent nature of this variable in Nigeria, which discourages farmers from investing appropriately in their fields, due to anticipated fear of competition in the rice market.

The results generally suggest that, increasing yield levels for paddy rice in Nigeria and ensuring stability requires interplay of biophysical, socio-economic and structural forces. By estimates for the current study, bridging of the demand-supply gap through improvement in yields can be realized through initiation of measures to address inefficiencies in the supply chain to ensure appropriate transmission of price increment, promotion of local rice consumption to ensure ready market for farmers in times of increasing output (to help increase their capital and financial base), addressing soil fertility challenges through efficient use of fertilizer and regular management of fertility of rice fields, and increasing farmers access to credit to help them meet cost of relevant inputs of production. This latter suggestion could to a greater extent incite appropriate response of farmers to both price and non-price incentives in the country.

\section{References}

[1] Abubakar, S. (2013). Why Nigeria imports N1bn rice daily. DAILY TRUST http://allafrica.com/stories/201308080475.html

[2] Adedipe, N.O., Bakshi, J.S., Odegbaro, O.A., and Aliyu, A. (1996). Evolving the Nigerian Agricultural Research Strategy Plan: Agro-Ecological Inputs. The National Agricultural Research Project, Ibadan, 1-486pp.

[3] Ahmed, A.M. and Siddiqui, R. (1994). Supply response in Pakistan with "Endogenous" Technology. The Pakistan Development Review 33:4 Part II (Winter 1994) pp. 871-888

[4] Akpokodje, G., Lançon, F., and Erenstein, O. (2001). Nigeria's rice economy: State of the Art. West Africa Rice Development Association (WARDA), Bouake, Côte d'Ivoire

[5] Amanor-Boadu, V. (2012). Rice price trends in Ghana (2006-2011). Department of Agricultural Economics, Kansas State University. METSS-Ghana Research and Issue Paper Series No. 02-2012-June 2012

[6] Anderson, K. and Nelgen, S. (2012). Updated national and global agricultural trade and welfare reduction indexes, 1995 to 2010. World Bank, Washington DC
[7] Basorun, J.O. and Fasakin, J.O. (2012). Factors influencing rice production in Igbemo-Ekiti Region of Nigeria. Journal of Agriculture, Food and Environmental Science, 5(1):1-9

[8] Bingxin, Y. and Shenggen, F. (2009). Rice production response in Cambodia. Contributed paper prepared for presentation at the International Association of Agricultural Economists Conference, Beijing, China. August 16-22, 2009

[9] Boansi, D. (2013). Rice production in Ghana: Past, present and future. ISBN-13: 978-3659498220, LAMBERT Academic Publishing, Germany

[10] Cohen, M.J., Dunne, J.E.J., and Bruland, G.L. (2008). Spatial variability of soil properties in Cypress domes surrounded by different land uses. Wetlands 28:411-422. DOI:10.1672/06-182.1

[11] Cummings, J. (1975). The supply responsiveness of Indian farmers in the post-independence period: Major cereal and cash crops. Indian J. Agricultural Economics, 30(1): 25-40

[12] Daramola, B. (2005). Government policies and competitiveness of Nigerian rice economy. Paper presented at the 'Workshop on Rice Policy \& Food Security in Sub-Saharan Africa' Organized by WARDA, Cotonou, Republic of Benin, November 07-09, 2005

[13] Defoer, T., Wopereis, M.C.S., Jones, M.P. Lançon, F., Erenstein, O., and Guei, R.G. (2004). Challenges and technical opportunities for rice-based production systems for food security and poverty alleviation in Sub-Saharan Africa. Proceedings of FAO Rice Conference, Rome, Italy, 12-13 February, 2004.

[14] Engle, R.F. and Granger, C.W.J. (1987). Co-integration and error correction: Representation, estimation and testing. Econometrica, 55:251-276

[15] FAOSTAT (2013). Agricultural production database. Food and Agricultural Organization of the United Nations, FAO, Rome, Italy. Accessed on June14, 2013 http://faostat.fao.org/site/703/default.aspx\#ancor

[16] Fashola, O.O., Imolehin, E.D., and Wakatsuki, T. (2007). Water management practices for sustainable rice production in Nigeria. Nigeria Agricultural Journal, 38: 40-48. DOI: http://dx.doi.org/10.4314\%2Fnaj.v38i1.3247

[17] Grunwald, S., Corstanje, R., Weinrich, B.E., and Reddy, K.R. (2006). Spatial patterns of labile forms of phosphorus in a subtropical wetland. Journal of Environmental Quality, 35:378-389 DOI:10.2134/jeq2005.0042

[18] Harris, R. (1995). Using co-integration analysis in econometric modelling. Oxford University Press, London

[19] Harris, R. and Sollis, R. (2003). Applied time series modelling and forecasting. Durham University. John Wiley \& Sons

[20] IRRI. World Rice Statistics, International Rice Research Institute. Accessed on June 14, 2013 http://ricestat.irri.org:8080/wrs/

[21] Johansen, S. and Juselius K. (1990). Maximum likelihood estimation and inference on co-integration with application to the demand for money. Oxford bulletin of Economics and Statistics, 52:170-209 
[22] Kuwornu, J.K.M., Izideen, M.P.M., and Osei-Asare, Y.B (2011). Supply response of rice in Ghana: A co-integration analysis. Journal of Economics and Sustainable Development, 2(6):1-14

[23] Lütkepohl, H. and Krätzig, M. (2004). Applied time series econometrics. Cambridge University Press, New York

[24] Molua, E.L. (2010). Response of rice yields in Cameroon: Some implications for agricultural price policy. Libyan Agriculture Research Center Journal Internation, 1(3):182-194

[25] Molua, E.L. (2008). Turning up the heat on African Agriculture: Economic impact of climate change on agriculture in Cameroon. African J. Agricultural and Resource Economics, 2(1):45-64

[26] Mulwanyi, A., Hutagaol, P., and Sinaga, B.M. (2011). Impact of rice purchasing policy on welfare of both producers and consumers in Indonesia. J. ISSAAS, $17(2): 48-57$

[27] Mythili, G. (2008). Acreage and yield response for major crops in the pre- and post-reform periods in India: A dynamic panel data approach. Report prepared for IGIDR-ERS/USDA Project: Agricultural Markets and Policy. Indira Gandhi Institute of Development Research, Mumbai.

[28] Newey, W.K. and West, K.D. (1987). A simple positive semi-definite, heteroskedasticity and autocorrelation consistent covariance matrix. Econometrica 55(3):703-708

[29] Norman, J.C. and Kebe, B. (2006). African smallholder farmers: Rice production and sustainable livelihoods. International Rice Commission Newsletter (FAO), 55:33-44

[30] Ogazi, C.G. (2009). Rice output supply response to the changes in real prices in Nigeria: An autoregressive distributed lag model approach. Journal of Sustainable Development in Africa, 11(4):83-100

[31] Omonona, B.T. (2013). Fertilizer profitability across Nigeria's diverse agro-ecological zones and farming systems. At the Nigeria launch of 'Guiding Investments in Sustainable Agricultural Intensification in Africa (GISAIA)', Abuja. June 17, 2013

[32] Phillips, P.C.B. and Ouliaris, S. (1998). Testing for co-integration using principal component methods. Economics Dynamic and Control, 12:205-230

[33] Townsend, T.P. (2001). World cotton market conditions. Beltwide Cotton Conferences, Proceedings, Cotton Economics and Marketing Conference, National Cotton Council, Memphis, TN pp 401-405

[34] WARDA (2003). The Nigerian rice economy in a competitive world: Constraints, opportunities, and strategic choices. Strategy for rice sector revitalization in Nigeria

[35] Yeong-Sheng, T., Survani, D., Aswani, F.M.N., and Nurjihan, I. (2009). Acreage response of rice: A case study in Malaysia MPRA Paper No 15300. University Library of Munich, Germany

[36] Zeigler, R.S.(2012) Advancing cutting-science to boost rice production, increase farmers' incomes and conserve the environment. International Rice Research Insitute. March 15, 2012 https://www.cgiarfund.org/sites/cgiarfund.org/files/Images/b bl_march15_2012_RZEIGLER.pdf

[37] Other source: Index Mundi, $\mathrm{http} / / /$ www.indexmundi.com/nigeria/demographics_profile.h tml 